\title{
MILITARY-HISTORICAL RECONSTRUCTION OF THE MIDDLE AGES IN UKRAINE AT THE BEGINNING OF THE $21^{\mathrm{ST}} \mathrm{C}$.
}

\author{
Valentyn Dolhochub \\ Postgraduate Student, Odesa I. I. Mechnikov National University, Ukraine \\ e-mail: dolhochub@gmail.com, orcid.org/0000-0001-7719-7364
}

\section{Summary}

In this article genesis and evolution of the medieval warfare game reproduction in Ukraine is considered on the basis of web-publications and memoirs of the reconstructors. The reconstruction movement includes the clubs, associations and informal groups of interested people, who study and reproduce the costume, armor, weapon and tactic of certain epoch. The typical model of historical reconstruction club creation is analyzed and the extension of such clubs net in the 1990-2000s is traced. The author pays attention to places (spaces) of reconstruction and to subcultural folklore of the historical reconstructors. The features and specificity of the main festivals of historical reconstruction in Ukraine ("Ancient Medzhybizh", "Terra Heroica", "Tu Stan '!", "Rus` Peresopnytska", "Medieval Hotyn") are investigated. Also the author put attention to some technical characteristics of the reconstructed weapon, used in different types of contests and field games. The issues of historical authenticity and identity of the reconstructors are examined as a central problem of reconstruction process.

Keywords: youth movement, festivals, role-playing, historical fencing, medieval combat, subculture.

DOI: https://doi.org/10.23856/4505

\section{Introduction}

The phenomenon of military-historical reconstruction emerged and quickly spread around Ukraine in the late 1980-s. Reconstruction is this context means reconstitution of material and technical culture and events (as a game or simulation) of certain historical epoch using archeological, written and pictorial sources.

As structural preconditions of this phenomenon we can name, firstly, folkloristic reconstructions and interest around "ethnic antiquities" that was increasing in the USSR since the end of the 1960-s and, secondly, military-patriotic volunteer search work, executed by out-ofschool centers at that time too.

So it isn 't strange that contemporary movement of the military-historical reconstruction in Ukraine is divided on two large streams: reconstruction of the Middle Ages and Early Modern time and reconstruction of the conflicts of the $20^{\text {th }} \mathrm{c}$. (especially two world wars and the civil war in Ukraine). In this research we consider the first of these streams.

\section{A brief history of the movement}

The military-historical reconstruction of the Middle Ages during three decades has already formed its own subculture in Ukraine. The space of discourse and practices of this subculture partly intersects with the spaces of other subcultures: role-players, tolkienists, rockers and neopagans. Reconstructors are usually "adepts" of several among these subcultures. 
Scientific investigation of military-historical reconstruction of the Middle Ages in Ukraine isn't developed: there are no synthetic monographies, a few articles are written by historians and folklorists (Aleschenko, 2012; Petrenko, 2012) or by specialists in touristic business and economical geography (Anipko, 2015; Hajday \& Havrylenko, 2012). In 2014 Ukrainian State Center of school education introduced the scientific and technical program "Historical reconstruction" that includes theoretical and practical studying of methods of the late Medieval warfare reconstruction (Ryazantsev, 2014).

As Odesa reconstructors assume (and, in our point of view, this situation is typical), their activity began in tolkienistic groups in the end of the 1980-s that regular often met in certain places (Lanzheron beach), organized camping out of the city, played scenes from the books of J.R.R. Tolkien and tried to reproduct the material culture of the characters (Na Moldavanke otkrylsya perviy $v$ Odesse zal istoricheskogo fehtovaniya, 2014). After a while some people, who were interested in accurate reconstruction of military, everyday and spiritual aspects of life of certain historical epoch, separated from this community. Thus "reconstructors" divided from the "role-players", although border between them seems to be illusive.

Since the middle of the 1990-s the military-historical reconstruction of the Middle Ages was named as "knights combat" or "medieval combat". In May of the 1998 one of the first "knights festivals" took place near Kamianets-Podilsky. It was devoted to the City Day and it wasn't concentrated on certain epoch or region, but it emphasized just a process of competition in armor and with swords. These first festivals ("Sokolynyi kubok" ["Falcon cup"] in 1999 among them) contemporary reconstructors of Kamianets-Podilsky call "pseudo-knightly" (Pustynnikova, 2017) because of the lack of authenticity.

On the edge of the 1990-2000-s historical reconstruction clubs began to spread widely and to form a net. Usually they were created by similar scheme: in some location initiative group of 3-4 persons emerged, they visited a festival or field game (see further about the typology of reconstruction games), learned the experience of already existed clubs and with their help started their own development. Purchase or mastering of the armor, game weapon and civil costume of certain epoch, trainings, local games and festivals organizing were the most important parts of this development.

It's very difficult to rebuilt the chronology of creation and development of particular reconstruction clubs, because such communities are often informal, with small quantity of members. Sometimes they disintegrated without any traces, except memoirs of their former members. That's why it would be more expedient to consider the history of reconstruction festivals and meetings.

The earliest Ukrainian festivals of historical reconstruction - "Ancient Medzhybizh" (since 2003), "Terra Heroica" (since 2004, Kamianets-Podilsky), "Tu Stan'!" (since 2006, Urych in L'viv Oblast) - showed themselves as durable than the later festivals and they are continued till nowadays.

In 2006 L'viv club of historical reconstruction "Silver wolf" organized international festival of medieval culture "Ancient L'viv" in the Museum of Folk Architecture and Rural Life named after Klymentii Sheptytskyi. L'viv of the 13-14 th centuries ("time of the blossom of this town") was the topic of this festival. The participants presented 5 countries and weren 't united by a certain style. The second and the third festival took place in 2010 and 2012.

In 2007 in Lutsk Castle the festival "Staleva Troyanda" ("Steel Rose") was held. Principles of the historical reconstruction movement at that time can be understood with one detail: this festival was organized by Odesa (!) regional federation of martial arts and wellness systems, collaborated with Lutsk clubs "Helm" and "Knight Fellowship of Volyn Land" ["Братство 
Рицарське Землі Волинської”] ("Staleva Troyanda" u Lutsku, 2007). This festival hadn't clearly defined stylistics and emphasized entertaining and competition aspects of "knights" combat. Thus, in the middle 2000 -s reconstruction movement already had strong organization forms - regional and interregional associations.

On the edge of the 2000-2010-s in Ukraine not durable or single time local and regional festivals arose: in 2008-2011 "Mstyslav Fest" took place in Chernihiv; in 2012 "Stara Fortetsya" ("Old Castle") was held in Trostyanets (Sumy Oblast); in Bilhorod-Dnistrovsky, except regular events of Odesa reconstructors, took place "Bilyi Bastion" festival ("White Bastion") that was concentrated on the medieval everyday life reconstruction (Festival istoricheskoy rekonstruktsii "Beliy Bastion", 2012). In the latter festival military aspect pursued the aim of experience exchange, but not of entertainment, as in other festivals.

Combination of both aims can be noticed in military-historical events, devoted to certain battles - for example, reconstruction of Zboriv battle (1649) and Hotyn battle (1621), both in 2009. The participants studied special features of costume, weapon and tactic of $17^{\text {th }} \mathrm{c}$.

One of the achievements of military-historical reconstruction movement in Ukraine is the opening of "The Park of Kyiv Rus"” in 2010 near Kopachyv in Kyiv Oblast. This project was funded by organization "Slavic fund". Despite private stakeholders, the project invited G. Ivakin, head's assistant of the NASU Institute of Archeology, as scientific administrator (Drevnyi Kyiv u parku "Kyivska Rus ", 2021). In this park Kyiv Detinets (fortified town center) of the 10-13 centuries is reconstructed, many regular festivals and events of historical reconstruction are taken place there.

In the end of the 2016 Ministry of youth and sports of Ukraine added "medieval combat" in a list of admitted types of sport (Serednyovychnyi byi vyznaly vydom sportu $d$ Ukrajini, 2016).

Political crisis in Ukraine in 2013-2014 showed that reconstructors of Middle Ages in Ukraine often are social active people, engaged in the "street activism". Maksym Shymko, a participant of Vinnytsia historical reconstruction club "Bilyi vovk" ["White wolf"] was killed by a sniper during Euromaidan; Anatolyi Kalin, founder of Odesa historical club "Porubizhna varta" ["Frontier guards"] died during street clashes and fire in Odesa on the $2^{\text {nd }}$ of May, 2014. Moreover, political processes made some changes in the whole life of some clubs and festivals. Annual festival "Staleva liha" ["Steel League"], which was holding in Odesa since the early 2000-s, in 2014 moved to Sudak (Crimean peninsula) because of political position of its founder, D. Koksharov, and some of his colleagues (Chast 'odesskih "rytsarey" perebralas ' $v$ okkupirovanniy Krym, 2014).

In 2021 clubs of historical reconstruction of Middle Ages (or historical fencing clubs) exist in every regional center of Ukraine and also in towns, advantageous for this activities because of their historical sights (Kamianets-Podilsky, Bilhorod-Dnistrovsky, Hotyn, Medzhybizh etc.). Some of them are concentrated on the military-historical reconstruction of certain epoch: for example, club "ВЪверица" [ancient word for squirrel and a small coin in Kyiv Rus'] reproducts style of Kyiv principality of the $11-13^{\text {th }} \mathrm{cc}$. (Klub istorychnoyi rekonstruktsyi "Viveritsia", 2016); "Vitaliyery" from Dnipro reconstructs warfare of North Europe of the 14-15 cc. (Klub istoricheskoy rekonstruktsii "Vitaliery", 2021). Some of them orient on two or more epochs: club "Tangar" (Odesa) reconstructs English knights of the $14-15^{\text {th }} \mathrm{cc}$. and musketeers of Cossack hetman Ivan Vyhovskyi, who lived in the $17^{\text {th }} \mathrm{c}$. (Rekonstruktsiya, 2017); "Kamianets-Podilsky military-historical fellowship" reproducts warfare style of Kamianets-Podilsky guards of the second part of the $15^{\text {th }} \mathrm{c}$., first third of the $17^{\text {th }} \mathrm{c}$. and the beginning of the $20^{\text {th }}$ c. (Sait Kamyanets-Podilskoho viyskovo-istorychnoho tovaristva, 2021). However, some 
clubs don 't connect themselves with certain epoch and territory (e.g. "Luches'k" from Lutsk, "Shpora" from Zhytomyr).

As well as everywhere in the world, ancient fortifications are popular places of the military-historical reconstruction of the Middle Ages. In the $19^{\text {th }}$ c. they lost their military function and often they became ruins. Contemporary festivals give an opportunity of regular repair and care of the antiquities at least for the tourists.

Let's consider some cases of such places.

In Medzhybizh the festival "Ancient Medzhybizh" (in the end of August) has been held since 2003 and the festival "Winter Tower" (after Orthodox Christmas) - since 2010. They are organized by Khmelnitsky military-historical reconstruction club "Voyin" ["Warrior"] and Ukrainian State historical reserve (such collaboration occurs in other cases too).

In Kamianets-Podilsky the largest in Europe festival of military-historical reconstruction of the $17^{\text {th }} \mathrm{c}$. "Terra Heroica" has been held since 2004. Accurate reproduction of costume, weapon, armor and tactic of the named epoch are its constitutive features. The participants play for Ukrainian Cossacks, Moskovian Streltsy, Crimean Tatars and Transylvania warriors, as well as other European armed formations (musketeers, hajduk etc.). Infantry and cavalry tactics, shooting from light cannons and hand guns are reconstructed; sham buildings are fired, communication between squads carry out by flags and kettledrums (Pustynnikova, 2017).

Annual festival “Tu Stan!”, which is held near Urych in L'viv Oblast since 2006, has other specification. Ancient Rus', Kingdom of Galicia-Volhynia and Mongol raids are its topic. Except typical reconstruction of costume, armor and weapon, in 2009-2010 catapults and rams were used during group battle ("Tu Stan!" - 15 rokiv viddani istoriji, 2021).

In 2010-2011 large international festival "Battle of Nations" was held in Hotyn Castle. It gathered participants from 4 countries in the first year and from 7 countries in the second (Ukraine, Russia, Belarus, Poland, Germany, Italy, Canada). The festival was organized by "Association of the Middle Ages reconstructors" from Kharkiv. After that "Battle of Nations" began to move from country to country: in 2012 it was held in Warsaw with support of the "International association of the Middle Ages historical reconstructors" (12 national teams) (Istoricheskoye fehtovaniye, 2012). On the other hand, in Hotyn the new festival - "Medieval Hotyn" - has been held. In 2012 during this festival reconstruction of mass cavalry battle and clashes on spears were reconstructed at first in Ukraine.

Since 2012 in Peresopnytsia (Rivne Oblast) historical reconstruction club "ВҺверица" [see above; "Squirrel" / "Small coin"] and archeological center "Peresopnytsia" celebrate the festival of reconstruction of the 10-13 cc. named "Rus' Peresopnytska". Participants should comply with the rules of strict authenticity: the weapon should fit armory of that epoch and territory; characteristics of the weapon's mass and dimensions should completely replicate the originals (except flails, horseman's picks and axes with a blade longer than $5 \mathrm{~cm}$ ), but the tips of spears should be blunted, the tips of arrows and darts should be made from soft amortizing material (Bojovi pravila, 2015).

The largest festivals of historical reconstruction in Odesa and Odesa Oblast are "Porohova Vezha" ["Powder Tower"] (in Odesa central park named by Taras Shevchenko), "Casta Moncastro" "Cup of Bessarabia", "Akkermanskyi klynok" ["Akkerman Blade"] (in Bilhorod-Dnistrovsky Castle). These festivals don't have strict historical topic, the participants represent military culture and tactics of the epochs and territories, chosen by themselves or their clubs. 


\section{Historical reconstruction as regular practice}

The military-historical reconstruction can be considered as a systematic activity of individuals (reconstructors) and groups (clubs, associations).

The first component of this activity is a research of certain period by adequate sources (written, archeological, iconic) and scientific publications. A part of the reconstructors have historical or archeological education, sometimes - an academic degree. However, most of them train their skills of historical sources analysis by themselves or with more experienced members of the club. Archeological and iconic sources are very important for the reconstructors, because they allow to see directly the costume, weapon, warriors posture of certain epoch.

The second component is purchase or mastering of the historical constume and game weapon. This process is the most laborious and problematic, because it induces a number of issues: authenticity of material, color, cut and form, mass and dimensions of the weapon, thus juridical status of this weapon nowadays. Newcomers often buy the first kit of clothes, armor and weapon, since "in Ukraine market of such things have already form because of the Internet" (Pustynnikova, 2017). However, many reconstructors have a desire to make "historical things" by themselves, so they try to study traditional handcrafts (blacksmithing, authentic sewing, carpentry, pottery etc.). Also this component includes regular training with the weapon.

The third component is using the knowledge, skills and things during the reconstruction game. O. Petrenko proposes the typology of reconstruction and role games in relation to their scale:

1) board, verbal and textual games;

2) "languedocs" in subcultural slang, that means event in close building with quantity of participants less than 50 ;

3) town games or local tournaments, competition between the clubs;

4) field games - the largest among them, that means travelling to certain location in the countryside and duration 3-7 days (Petrenko, 2012).

The convent is one more type of reconstors` events. It means planned meeting for the experience exchange and communication.

The field game or reconstruction festival begins from idea / conception, created by the "master" or "master group" (initiators). The developing of idea can last a few months or a year. Members of the "master group" divide the responsibilities of the general conception, the plot line (if it exists), supervision of stylistic authenticity, relations with authorities, guard, medical and food support. "Location masters" manage the game on the certain territory (if the field is divided on several "camps", teams). "Graveyard master" works with the players after the "death" of their characters. "Play technicians" are the players, whose characters are subordinate the "masters" and are used for the plot providing (Petrenko, 2012).

Reconstruction of the battles during the field games and the tournaments submit to strict rules too. The duels often include categories "shield-sword" (both players have shield and bladed weapon), "sword-sword" (without shields), "halberds". Group battles imply the same quantity of the participants $(5 \times 5,21 \times 21)$; they are often named "buhurt".

During the "buhurts" every player can endure a number of hits, after that he/she should get out of the fight or fall down like a dead. The rules of the festival "Rus' Peresopnytska", for example, allow hits by the blades and pole weapon: helmet, corps, thighs, biceps. These rules include many details like "if helmet has no aventail and nose protection the hits in the neck and the face are forbidden" (Boyovi pravila, 2015). 
During the tournaments elimination contests are conducted with a circle system, final contests - with an Olympic one.

During the years of its existance the movement of the historical reconstruction in Ukraine has formed its own subculture with specific slang, folklore, stereotypes and identities. Folklore of the Ukrainian reconstructors was researched by L. Aleschenko (Aleschenko, 2012). She names anecdote, linguistic game, conversational folklore and topical folklore narratives as the most popular genres in this community. Subculture folklore regulates communication, creates an image of relatively closed society with some "esoteric" knowledge.

There is inside typology of the reconstructors in their subculture according their aims and measure of their immersion in the past: reconstructors, who reproduce material and technical details ("tin buttons of Tatar cavalry" (Pustynnikova, 2017)); "fighters", who are interested most of all in the battles; "goblins" / "pokemons" / "Martians" - people, who "don't stick to the rules of historical authenticity while forming of personal kits", "use excessive contemporary things and materials", create "chaotic collection of the historical things that couldn't be combined in reality" (Pustynnikova, 2017).

Opposite trends in the reconstruction movement can be illustrated by the "Kamianets-Podilsky military-historical fellowship" is fine example of "authenticity trend" in the reconstruction movement ("we have realized that hitting heads of each other isn't for us" (Pustynnikova, 2017)) and the Lutsk club "Luchesk" ("we aren 't historians and we rarely immerse in historical books; we are more interested in force interaction with other people and objects" (Suchansi lytsari, elfy ta mahy u Lutsku, 2014. The head of the "Kamianets-Podilsky military-historical fellowship" O. Zaremba says that "ideal aim of the reconstruction is a person of that time in authentic clothes, ammunition and even way of thinking" (Pustynnikova, 2017), but military-historical reconstruction (unlike the Neopagans, for example) very rarely begin to identify themselves with a human from the past completely. Furthermore, military-historical reconstruction often doesn't include reproduction of folklore and spiritual aspects of some ethnic traditional culture, so it rarely excite ethnic or national identity of the reconstructors.

\section{Conclusions}

The military-historical reconstruction of the Middle Ages as a practice of material culture and historical events reproduction became popular in Ukraine since the end of the 1990-s and has widely spread during the 2000-s. The reconstruction movement includes the clubs, associations and informal groups of interested people, who study and reproduce the costume, armor, weapon and tactic of certain epoch. The reconstructed objects are used actively during field games and festivals of historical reconstruction, held on the territory of abandoned or defined as culture heritage fortifications (castles, bastions).

The military-historical reconstruction also includes game contests with reconstructed weapon, which battle characteristics (blade sharpness and width, material of tip of arrow and spear), are consciously decreased. Blank shots from historical types of the fire-arms (handguns and light cannons) are allowed, as well as cavalry battles, pyrotechnics, authentic ways of non-verbal communication.

The movement of the military-historical reconstruction can be described as a system with its own orders, norms and rules (rules of fighting, of the field game organization etc.) and also as a subculture with certain values, style and folklore.

Personal aims and motivation of the reconstructors can vary from sincere interest in accurate reproducing of historical details to competitive and sportive aspects. It's important, in 
our point of view, that the identity of the reconstructors are limited by the subculture, they don't identify themselves with an image, or character of the game, so they keep in their mind an idea of historical, cultural and mental distance.

\section{References}

Aleschenko, L. V. (2012). Fol klor suchasnoho mista: istorychna rekonstruktsiya yak riznovid molodizhnyh subkul tur u systemi postfol kloru [Folklore of contemporary city: historical reconstruction as a type of youth subculture in a system of postfolklore] // Literatura. Fol klor. Probllemy poetyky. Kyiv: T. Shevchenko Kyiv National University [In Ukrainian].

Anipko, N. P. (2015). Viys kovo-istorychnyi turism v serednyovichnyh zamkah ta fortetsiah [Military-historical tourism in medieval castles and fortifications]. Naukovyi visnyk Chernivetskoho universitetu. Vol. 744-745: Geography. Chernivtsi. [In Ukrainian]

Bojovi pravyla [Combat rules] (2015). Retrieved from: https://vk.com/topic-70569103 32248279 [In Ukrainian]

Chast odesskih "rytsarey" perebralas v okkupirovanniy Krym [A part of Odesa "knights" moved to occupied Crimea] (2014). Retrieved from: http://dumskaya.net/news/chast-odesskih-rycarej-perebralas-na-okkupirovan-037706 [In Russian]

Drevnyi Kyiv u parku “Kyivska Rus "” [Ancient Kyiv in the Park "Kyiv Rus "”] (2021). Retrieved from: http://parkkyivrus.com/ua/pro-drevnij-kijiv/item/1-arkhitektura-i-dukh-velykoi-epokhy [In Ukrainian]

Festival istoricheskoy rekonstruktsii “Beliy Bastion” [Festival of historical reconstruction “White Bastion”] (2011). Retrieved from: http://viknaodessa.od.ua/krepost/?festival_beliy_ bastion [In Russian]

Hajday, S. V., Havrylenko, K. O. (2012). Istorychni festivali ta viys kovo-istorychni rekonstruktsiyi na osnovi istoryko-kulturnyh zapovidnykiv Ukrajiny [Historical festivals and military-historical reconstructions on the basis of the historical-cultural reserves]. Geographiya i turism. Vol. 23. Kyiv. [In Ukrainian]

Istoricheskoye fehtovaniye [Historicalfencing] (2012). Retrieved from: http:/lodessa-sport.info/ index.php? option $=$ com_content \&view $=$ article $\&$ id $=11156$ : istoricheskoe-fehtovanie-odesskie-rytsari-pouchastvujut-v-bitve-natsij [In Russian]

Klub istoricheskoy rekonstruktsii "Vitaliery" [Historical reconstruction club "Vitaliery"] (2021). Retrieved from: http://vitaliery.blogspot.com/ [In Russian]

Klub istorychnoyi rekonstruktsyi "Viveritsia" [Historical reconstruction club "Viveritsia"] (2016). Retrieved from: https://vk.com/veverica_bc [In Ukrainian]

Na Moldavanke otkrylsya perviy v Odesse zal istoricheskogo fehtovaniya [In Moldavanka district the first in Odesa center of historical fencing opened] (2014). Retrieved from: http:// dumskaya.net/news/na-moldovanke-uchat-sragatsya-kak-nastoyaschij-r-037636 [In Russian] Petrenko, O.S. (2012). Subkul tury rolyovykiv i rekonstruktoriv v Ukrajini [Subcultures of role-players and reconstructors in Ukraine]. Scientific journal of T. Shevchenko Lugansk National University. Vol. 2. Luhansk. [In Ukrainian]

Pustynnikova, I. (2009). Kozaky i goblolytsari. V Ukrajini-bum istorychnoyi rekonstruktsiyi [Cossacks and goblin-knights. Boom of the historical reconstruction in Ukraine]. Retrieved from: http://texty.org.ua/pg/article/solodko/read/6147/Kozaky_i_goblolycari_V_Ukrajini_ bum [In Ukrainian]

Rekonstruktsiya [Reconstruction] (2017). Retrieved from: http://tangar.org/rekonstrukciya/ [In Russian] 
Ryazantsev, E. E., Dejdysh, L. A. (2014). Navchanl 'na programa z pozashkil noyi osvity nakovo-tehnichnoho napryamu "Istorychna rekonstruktsiya" [Educational program of the out-ofschool scientific and technical education "Historical reconstruction"]. Kyiv: Ukrainian State Center of school education. [In Ukrainian]

Sait Kamyanets-Podilskoho viyskovo-istorychnoho tovaristva [Site of "Kamianets-Podilsky military-historical fellowship"] (2021) Retrieved from: http://kupa.in.ua [In Ukrainian]

Serednyovychnyi byi vyznaly vydom sportu d Ukrajini [Medieval combat is admitted as a type of sport in Ukraine] (2016). Retrieved from: https://sport.unian.ua/othersports/1703662-serednovichniy-biy-viznali-vidom-sportu-v-ukrajini.html [In Ukrainian]

"Staleva Troyanda" u Lutsku ["Steel Rose" in Lutsk] (2007). Retrieved from: http://lutsk. myneformat.com/2007/08/22/staleva-troyanda-u-lutsku/ [In Ukrainian]

Suchansi lytsari, elfy ta mahy u Lutsku [Contemporary knights, elves and magicians in Lutsk] (2014). Retrieved from: https://www.volynnews.com/news/culture/suchasni-lytsari-elfy-ta-mahy-u-lutsku-khto-vony/ [In Ukrainian]

"Tu Stan!" - 15 rokiv viddani istoriji ["Tu Stan!”-true-hearted to history for 15 years] (2021) Retrieved from: https://tustan.com.ua/history/[In Ukrainian] 